\title{
The State of Saving in Latin America and the Caribbean
}

Savings in an economy matter for development. At the macro level, savings determine how much a country can invest, and they have implications for growth and economic stability. At the individual level, savings give people a cushion to withstand unexpected income shocks, smooth consumption, and plan for the future.

Despite their significance, determining how much a country should save is not an easy task. Just like the "right" flying altitude of an airplane depends on factors such as wind speed, distance to destination, and weather conditions, aggregate saving rates in an economy depend on several factors that vary across countries and over time. In particular, saving rates are driven by: (a) demographic trends; (b) income growth and how that growth is distributed across generations; (c) people's income at different ages and stages of life; (d) pension and old-age living arrangements; (e) asset markets that permit households and firms to shift consumption from the present to the future; (f) individual preferences and varying levels of tolerance for uncertainty; (g) growth expectations; and ( $h$ ) the institutional framework, among other factors.' The interaction of all these factors determines the differential saving patterns across economies and over time. ${ }^{2}$

This book tells a story of unrealized potential and the role savings has played in the region's search for elusive growth. This chapter sets the stage for this story by describing household and aggregate saving patterns in the region and by defining the main terms and concepts that will be used throughout the book (see Box 2.1). It is the starting point for the discussion, the base on which policy must build. 


\section{BOX 2.1. WHAT IS SAVING?}

At the aggregate level, national saving ( $\mathrm{Sn}$ ) is defined as gross national disposable income (NDI) minus total consumption, based on national accounts data. This is the flow of saving generated within a period of time, usually a year. The saving rate is generally defined as the ratio of national saving to gross domestic product (GDP).

Aggregate national saving may be further decomposed into its private and public components, depending on who generates it:

$$
S_{n}=S_{\text {pri }}+S_{\text {pub }}
$$

Private saving $\left(\mathrm{S}_{\text {pri }}\right)$ is defined as the sum of household $(\mathrm{Hh})$ and firm saving (Bs).

$$
\mathrm{S}_{\mathrm{pri}}=\mathrm{Hh}+\mathrm{Bs}
$$

Household saving is the portion of the disposable income of families that is not devoted to current consumption; it comprises voluntary household saving and pension contributions. Firm saving is defined as cash flows-net revenues plus depreciation-minus dividends or firms' retained earnings. In practice, national accounts data in many countries do not permit the subcomponents of private saving to be identified separately. This reflects, among other factors, the prevalence of large informal sectors in developing countries that blur the boundaries between households and firms. When disaggregation can be done, the saving generated by firms that operate in the informal economy, such as family firms and self-employed workers-to the extent that it is measured-is bundled together with household saving.

Public saving (Spub) is defined as total public sector income minus current government expenditures. National accountants typically approximate this by adding up the overall fiscal balance of the public sector (OB)-including interest payments on debt-and public sector investment (PI).

$$
S_{\text {pub }}=O B+P I
$$

By definition, aggregate saving equals domestic investment ("real investment," which is the so-called "gross fixed capital formation") in closed economies because both concepts refer to national income that is not consumed when it is generated. Instead, open economies can rely on foreign saving as a complementary source of investment financing. Therefore, in open economies:

\section{Domestic Investment $=$ Total Saving $(\mathrm{TS})=$ National Saving $(\mathrm{Sn})+$ Foreign Saving (FS)}

where FS is the counterpart of the current account deficit in the balance of payments: that is, when a country runs a current account deficit, it imports 
BOX 2.1. (continued)

savings, (FS > 0); when it runs a current account surplus, it exports savings, $(\mathrm{FS}<0)$.

Some components of savings, such as pension contributions, are directly measured, but in most cases, savings are not directly observed. Thus they are usually approximated as the residual between measured income and consumption, which implies a double measurement error in the computation of saving flows. Notwithstanding, the international harmonization of national accounts records across countries allows for meaningful cross-country comparisons of saving rates.

a Gross National Disposable Income is equal to the Gross National Product (GNP) plus all net payments from abroad (i.e. net factor payments and net current transfers).

${ }^{b}$ Business saving is also referred to as corporate saving, retained earnings, undistributed cash flows, and the accumulated stock of saving as internal funds (or own funds).

c A country's GDP ( $Y$ ) is divided into four components of expenditure: consumption (C), Investment (I), government purchases $(G)$ and net exports $(X-M)$. In closed economies, $X-M=0$, and therefore $(Y-C-G)=I$, where the left-hand side of this equation is national saving.

d In open economies, the wedge between Saving (S) and Investment (I) is the current account balance $(C A B) \cdot C A B=(X-M)$ plus net total payments from abroad. Therefore, saving equals investment plus the current account balance.

\section{National Saving Rates: Comparatively Low}

Over the last 30 years, national saving rates in Latin America and the Caribbean have hovered below 20 percent of GDP, well below Advanced Economies and fast growing Asian countries (Figure 2.1). ${ }^{3}$ Even after controlling for factors such as demographics, income per capita, and growth performance, Advanced Economies and countries in Emerging Asia save, on average, 3 and 9 percentage points of GDP more, respectively, than countries in Latin America and the Caribbean. ${ }^{4}$

National saving rates in Latin America have varied significantly in recent decades. During the debt crises of the early 1980s, they fell to their historical minimum (11.5 percent of GDP in 1983), and during the 2003-06 commodity price boom, they temporarily surged above 20 percent of GDP. Although average saving rates in Emerging Asia have also fluctuated throughout this period, they have been consistently higher than in Latin America and the Caribbean by between 10 and 20 percentage points of GDP. In Advanced Economies, average saving rates have been relatively stable at slightly over 20 percent of GDP.

Figure 2.2 shows the distribution of average national saving rates from 1980 to 2014 in select regions. The line at the center of each box 
Figure 2.1 Gross National Saving Rates (percent of GDP), Simple Averages by Region

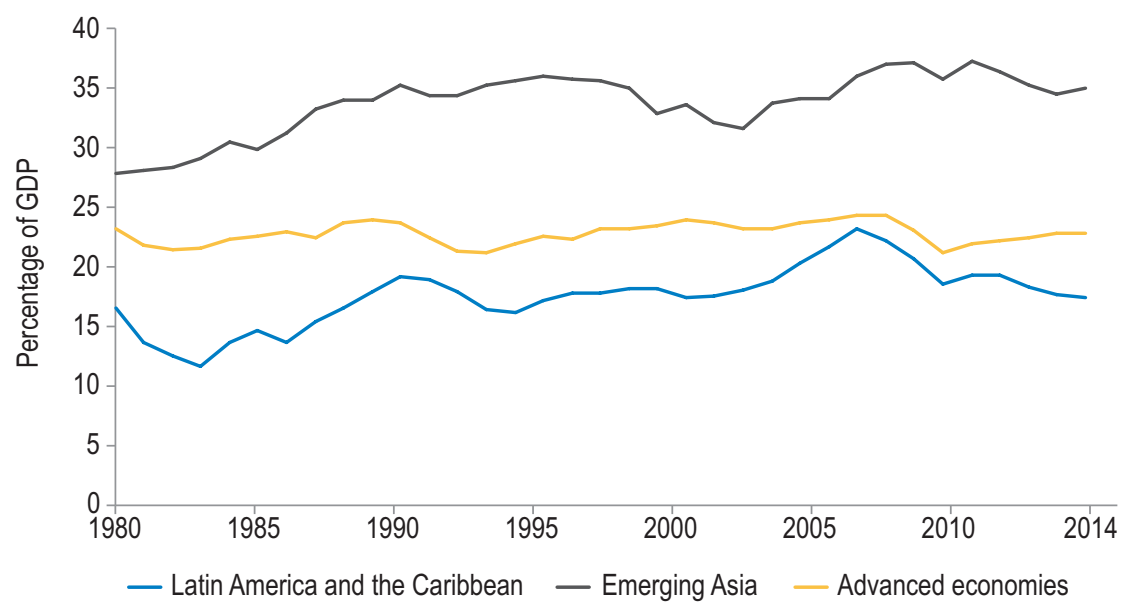

Source: Authors' calculations, based on data from World Economic Outlook database (IMF, 2015).

is the median of the regional distribution. The top and bottom edges of each box are the $75^{\text {th }}$ and $25^{\text {th }}$ percentile of the regional distribution respectively, and the line-ends plot the minimum and maximum. ${ }^{5}$ Tellingly, the median saving rate in Latin America and the Caribbean is closer to that of Sub-Saharan Africa and Advanced Economies-two

\section{Figure 2.2 Distribution of Aggregate Saving Rates by Region}

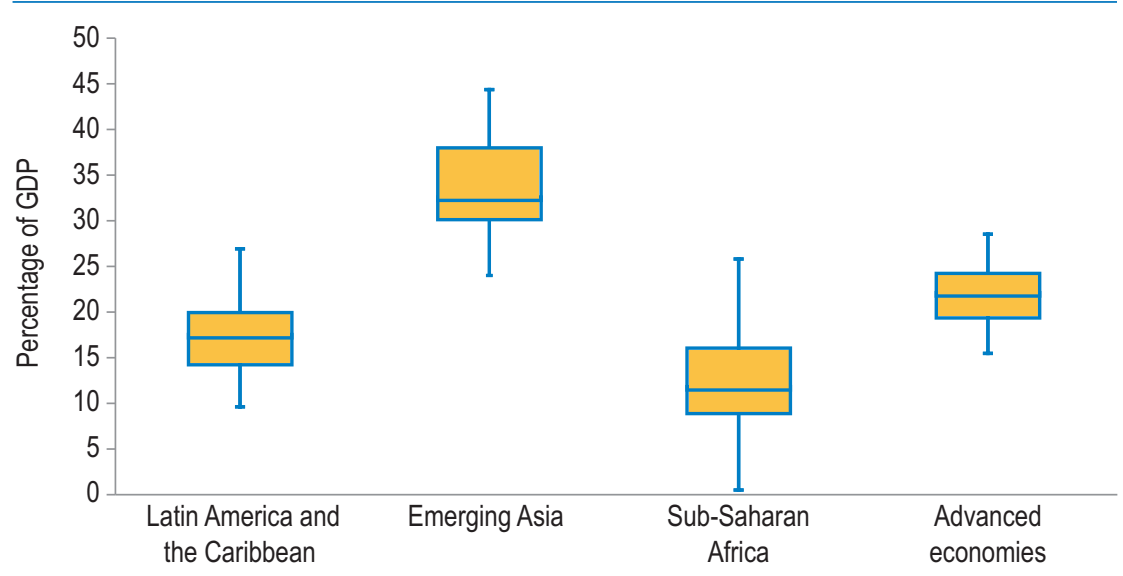

Source: Authors' calculations based on data from World Economic Outlook database (IMF, 2015). Note: Aggregate saving rates (percent of GDP) are computed as country averages of annual saving rates over the period 1980-2014. Each country's average is then grouped by region. 
Figure 2.3 Gross National Saving Rates in Latin America and the Caribbean

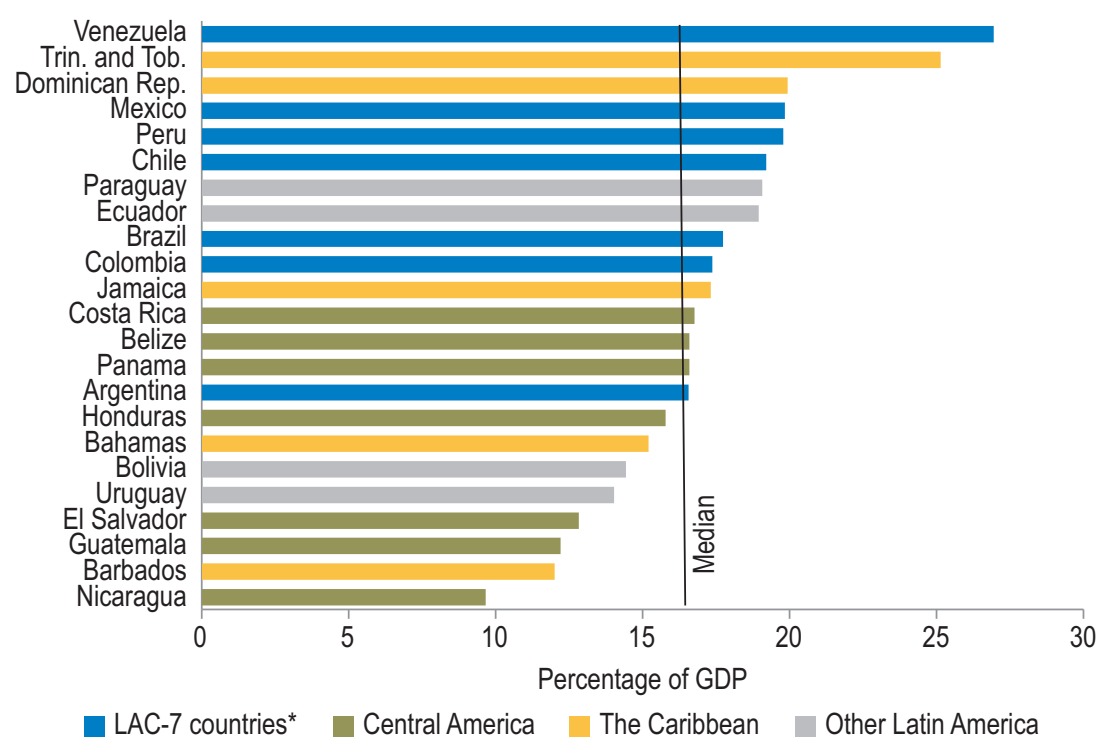

Source: Authors' calculations based on data from World Economic Outlook database (IMF, 2015). Notes: Aggregate saving rates (percent of GDP) are computed as country averages of annual saving rates over the period 1980-2014. The horizontal line is the sample median.

LAC-7 includes Argentina, Brazil, Chile, Colombia, Mexico, Peru, and Venezuela.

regions at opposite extremes of the world distribution of income per capita-than to Emerging Asia, a more comparable region in terms of income level. All told, national saving rates in Latin America and the Caribbean pale compared to almost every other world region, except Sub-Saharan Africa. ${ }^{6}$

Across subgroups of countries in Latin America and the Caribbean, median saving rates range between 14.7 percent of GDP in Central America (excluding Mexico) and 20 percent in the Caribbean region. Among the seven largest countries by income (LAC-7), ${ }^{7}$ median saving rates lie between these two extremes at 18.2 percent of GDP (Figure 2.3).

\section{The Private Sector: Taking the Lead}

The private sector does most of the heavy lifting when it comes to savings in Latin America-and throughout the world for that matter. Table 2.1 presents the shares of each subcomponent of total saving-public, 
private, and foreign-averaged over the period 1980-2014 for Latin America and the Caribbean, Emerging Asia, and Advanced Economies. Across these three regions, private saving leads the way, representing between 70 and 90 percent of total saving. Clearly, private saving plays a pivotal role in determining the level of total saving rates in all regions.

Although private saving rates represent the largest component of total saving in Latin America and the Caribbean, they are lower there than in both Emerging Asia and Advanced Economies. On the other hand, average public saving rates in the region are higher than in Advanced Economies and lower than in Emerging Asia. Compared to the other regions, foreign saving in Latin America and the Caribbean represents a relatively large share of total saving (3.5 percentage points out of 21 percentage points of GDP of total saving) and contributes a positive amount to total savings-meaning that, on average, the region has been a net importer of foreign saving for the past three decades (in sharp contrast to Emerging Asia).

While public and foreign components of saving contribute quantitatively less to total saving in Latin America, they nonetheless influence the variation of saving rates over time. Figure 2.4 shows that the importance of foreign saving in the region has been declining since the 1980s. It also shows that a temporary surge in saving rates, fueled by the 2005-09 commodity price boom, was driven largely by the expansion of public saving.

\section{Figure 2.4 Composition of Total Saving in the Region, 1980-2014}

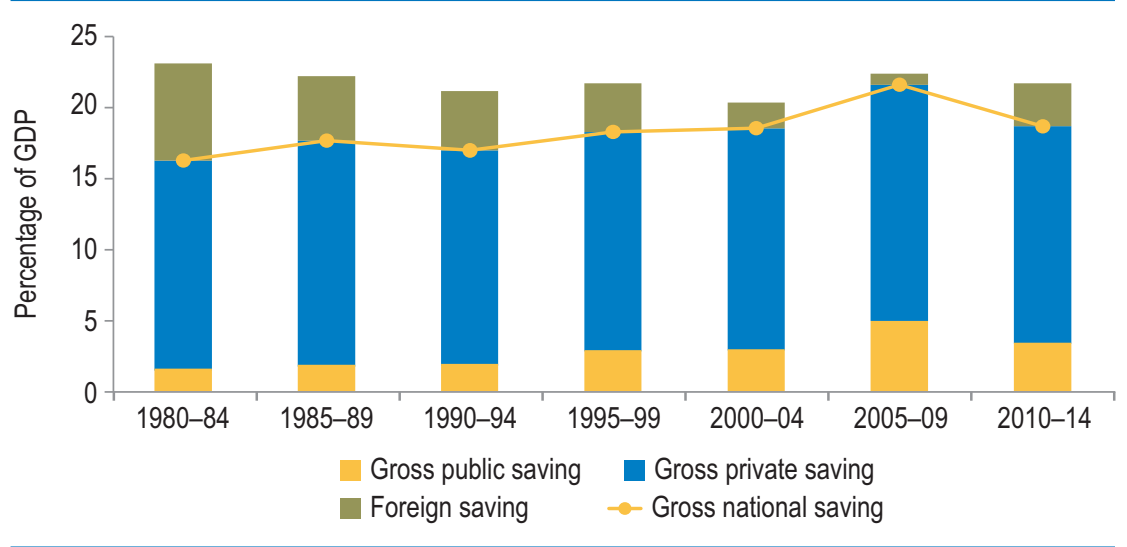

Source: Authors' calculations based on data from World Economic Outlook database (IMF, 2015). Note: Quinquennial averages computed over regional yearly averages. 


\section{Foreign Savings: A Secondary Actor}

Foreign savings can complement or decrease national savings, depending on whether a country is a net importer or exporter of foreign savings. Between 1980 and 2014, the median country in Latin America and the Caribbean was a net importer of savings (as in Sub-Saharan Africa and Advanced Economies), while the median country in Emerging Asia was a net exporter of savings (see Figure 2.5).

However, foreign savings are not high enough to pick up the slack for comparatively lower national saving rates in Latin America and the Caribbean (see Table 2.1). In fact, foreign saving rates (in absolute terms) are significantly lower than national saving rates in all regions.

\section{Figure 2.5 Distribution of Foreign Saving Rates by Region}

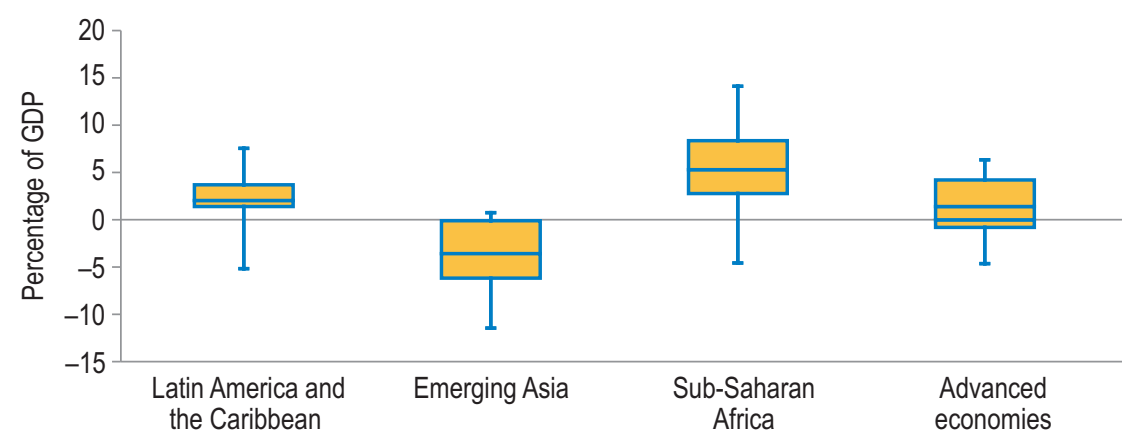

Source: Authors' calculations based on data from World Economic Outlook database (IMF, 2015). Note: Aggregate saving rates (percent of GDP) are computed as country averages of annual saving rates over the period 1980-2014. Each country's average is then grouped by region.

Table 2.1. Saving Rates by Sector, 1980-2014 (percentage of GDP)

\begin{tabular}{lcccc}
\hline Saving rates by region & $\begin{array}{c}\text { Latin America } \\
\text { and the } \\
\text { Caribbean }\end{array}$ & Emerging Asia & $\begin{array}{c}\text { Sub-Saharan } \\
\text { Africa }\end{array}$ & $\begin{array}{c}\text { Advanced } \\
\text { economies }\end{array}$ \\
\hline 1. Gross national saving & 17.5 & 33.7 & 13.8 & 22.8 \\
\hline 1.1 Gross public saving & 2.8 & 7.9 & 2.8 & 1.5 \\
\hline 1.2 Gross private saving & 14.7 & 25.8 & 10.9 & 21.2 \\
\hline 2. Foreign saving & 3.5 & -3.8 & 5.4 & 0.8 \\
\hline 3. Total saving & 21.0 & 29.9 & 19.2 & 23.6 \\
\hline
\end{tabular}

Source: Authors' calculations based on data from World Economic Outlook database (IMF, 2015). Gross national saving (1) is equal to gross public saving (1.1) plus gross private saving (1.2). Total saving (3) is equal to foreign saving (2) plus gross national saving (1).

Note: Statistics computed over country averages. 


\section{Businesses: The Biggest Savers-Worldwide}

The prevalence of large informal sectors in developing countries blurs the boundaries between households and firms. Many households are supported by self-employed workers who run their own businesses, usually in the informal economy. This limits the availability of cross-country data on private saving for clearly distinguishing between households and businesses. Despite the difficulties, two recent papers (Bebczuk and Cavallo, 2016; Grigoli, Herman, and Schmidt-Hebbel, 2015) compile the available data from international and national sources. ${ }^{8}$ While the studies have different samples and assumptions, both reveal that, on average, business saving is the largest contributor to aggregate private saving in most countries, including Latin America and the Caribbean (see Figure 2.6). ${ }^{9}$

Firms save because internal funds are a cheaper source of investment financing than external credit, which includes the costs of financial intermediation (see Myers and Majluf [1984] on the pecking order theory of finance). Households, in turn, are the owners of the firms, which means that, in principle, the distribution of savings within the private component should not be particularly relevant.

However, as discussed in detail in Chapter 1 (Box 1.1), business saving and household saving are not perfect substitutes. There are many

Figure 2.6 Composition of Private Saving, World and Latin America and the Caribbean

a. Contribution to GNS by sector: World average

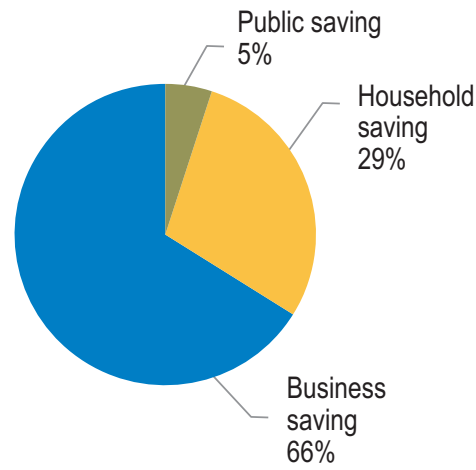

b. Contribution to GNS by sector: Latin America and the Caribbean average

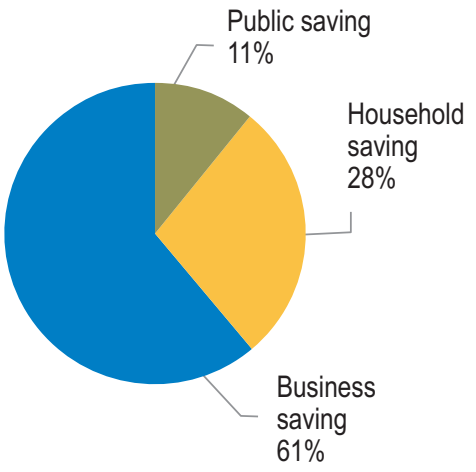

Source: Authors' calculations based on data from Bebczuk and Cavallo (2016). Note: The figure shows the contributions to Gross National Saving (GNS). 
reasons why households do not perceive the saving done by firms as their own. For instance, the majority of households are not direct owners of firm shares; there is asymmetric information between firm owners and managers; and, in many countries, there is differential taxation of corporate profits and capital owner income. ${ }^{10}$

Importantly, household savings per se have important welfare implications. Households use savings to smooth consumption and to cope with unexpected income shocks. Savings help households manage risks better, especially when they face liquidity and/or credit constraints. Therefore, although their relative contribution to aggregate saving is smaller than the saving generated by businesses, fostering the accumulation of household savings is important to sustain an equitable development path. With this in mind, the rest of the chapter is devoted to the analysis of household savings (see Box 2.2 on measurement issues related to household savings).

\section{Farewell to the Demographic Dividend}

According to the most well-known theory of consumption and saving behavior, Modigliani's Life-Cycle Hypothesis ( $\mathrm{LCH}$ ), individuals borrow when they are young, save during their working years, and then deplete their savings once they reach retirement. When economies are growing, younger generations tend to be wealthier and save more, leading to a positive relationship between growth and aggregate saving.

During a demographic transition, a country moves through three broad phases (see Bloom, Canning, and Sevilla, 2001) that vary in their impact on the dependency ratio (the ratio of the young and old-age populations to the working-age population). In the first phase, advances in healthcare reduce mortality rates, particularly infant mortality, thereby increasing the ratio of dependents (in this case, children) to the working age population. In the second phase, lower fertility leads to a decrease in dependency rates, as the number of incoming (young) cohorts declines while the number of adults entering the labor force rises. In the last phase, longer average life expectancy leads to an aging population and a corresponding increase in old age dependency rates and, therefore, overall dependency rates. This cycle lasts several decades, but the duration of each stage varies across countries.

During the second phase (also known as the "demographic dividend"), age dependency rates decline. This, in turn, implies that the 


\section{BOX 2.2. HOUSEHOLD SAVING RATES: MEASUREMENT ISSUES}

National accountants rely on indirect data sources and make simplifying assumptions to construct disposable income and consumption statistics from which they can derive saving as a residual between the two. Consequently, there is considerable measurement error in the resulting estimates of saving rates. ${ }^{\text {a }}$

Alternatively, household saving rates can be computed using micro-level data from household surveys. Since these surveys focus on measuring living conditions, they typically collect detailed income and expenditure modules that in turn can be used to compute saving rates. These surveys are generally representative of the country as a whole and, as such, the estimates they provide are comparable to those coming from national accounts.

However, several studies show that there are significant discrepancies between household saving rates computed from national accounts and those computed from household surveys. ${ }^{b}$ On the one hand, household surveys have the potential to provide more accurate measures of both disposable income and consumption at the household level because they can capture transactions in informal sector transactions. On the other hand, there are misreporting biases in income or consumption that may be more salient among specific income or occupational groups. ${ }^{c}$ For example, higher-income households may have a more varied consumption basket; consequently, they could have a higher likelihood of forgetting or misreporting these expenditures than poorer households. In addition, estimated saving can be negative for households that can finance expenditures using credit or accumulated savings over a given time frame, or among those that tend to underreport household income. This is sometimes reflected in negative national average saving rates, particularly when wealthier segments of the population are underrepresented in the sample.

What then is the informational value of household saving rates computed from household surveys? The advantage of these data sources is that they allow the definition of household consumption to be fine-tuned by taking into account the heterogeneity in saving vehicles used in different contexts. For example, in countries with limited access to diversified saving instruments, some households may choose to save by purchasing durable goods. Similarly, in countries with deficient public education and health services, households may choose to invest in these services to accumulate human capital. Although not all expenditures in durables or health and education are undertaken as a form of saving, the alternative saving rates (computed by excluding certain types of expenditures) can be informative, especially in settings where nontraditional forms of saving are expected to be important, as is the case in Latin America and the Caribbean.

Figure B2.1 reports the ratio of alternative definitions of household saving rates to standard definitions (i.e., saving rates using all categories of consumption without discriminating) for select Latin American and Caribbean 


\section{BOX 2.2. (continued)}

countries, and for a smaller set of Asian countries and Advanced Economies used as comparators. ${ }^{d}$ Excluding the consumption of durable goods from expenditures generates a substantial increase in saving rates in all regions. On average, saving rates computed assuming that durables are an alternative form of saving, increase by 50 percent, relative to the traditional definition in Latin America and the Caribbean. This increase is even larger amongst the comparator countries: the ratio of the alternative definitions to the traditional definition of saving rates is approximately 2.0 and 2.4 amongst the control groups in Asia and Advanced Economies, respectively. The regional differences reflect the fact that households in countries of the comparator groups spend a higher fraction of their incomes on durable goods.

Excluding education and health spending from total consumption has a comparatively larger effect on the resulting saving rates proxy in Latin America and the Caribbean than in the control groups. On average, saving rates in the region are 1.6 times higher after removing education and health expenditures from consumption, while they are 1.3 and 1.4 times higher in Asian and Advanced Economies in the comparator samples, respectively.

In summary, household saving rates are estimated to be higher when computed using a different definition of saving that considers expenditures in durables or in health and education as alternative forms of saving rather than

\section{Figure B2.1 Alternative Definitions of Saving Rates vs Traditional Definition}

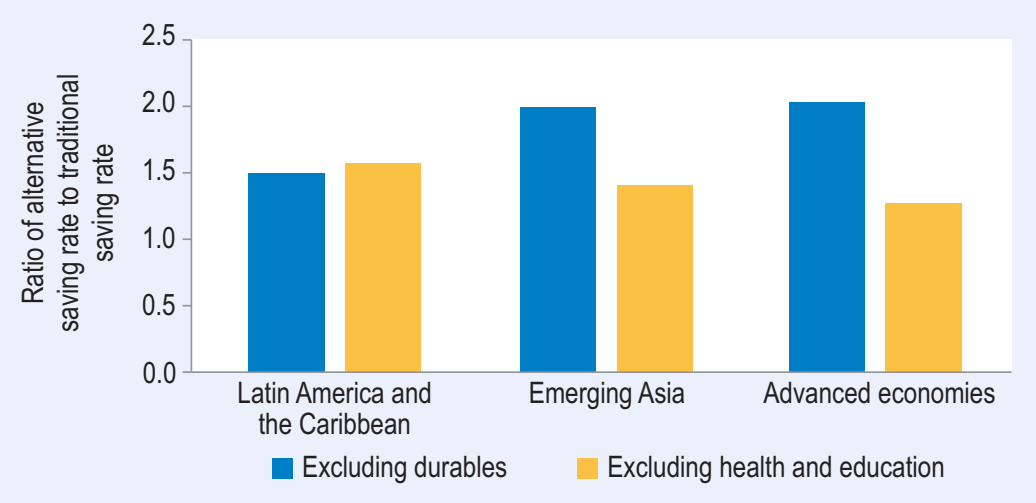

Source: Authors' calculation based on data from Bebczuk et al. (2015); Székely, Mendoza, and Karver (2015); Hernani-Limarino, Jiménez, and Mena (2015); and Centro de Estudios Educativos y Sociales (CEES). Estimates for Mexico come from Székely, Mendoza, and Karver (2015) and for Bolivia come from Hernani-Limarino, Jiménez, and Mena (2015). Estimates for all other Latin American and Caribbean countries (Argentina, Brazil, Colombia, Ecuador, El Salvador, Guatemala, Nicaragua, Panama, Peru) come from Bebczuk et al. (2015). Estimates for Emerging Asia (Sri Lanka, Taiwan, Thailand) and advanced economies (United States, France, Japan) come from Centro de Estudios Educativos y Sociales (CEES).

Note: Saving rates measured as a percentage of household income. The use of short-term (credit card) credit to finance consumption may inflate the estimated consumption, and thereby depress saving. Naturally, the opposite is true when the debt is paid-off. 


\section{BOX 2.2. (continued)}

consumption. However, the extent to which these expenditures are actually used as saving vehicles is unobservable, and can vary across countries depending on the context. Therefore cross-country comparisons of alternative saving rates should be interpreted with caution.

Having said this, the evidence reported in figure B2.1 suggests that households in Latin America and the Caribbean spend higher shares of their disposable income on longer-term investments in human capital than households in Asia and in Advanced Economies. The result is a relatively larger increase in alternative saving rates when excluding health and education services from consumption compared to traditional saving rates (i.e., computed without discriminating by categories of consumption). This evidence suggests that traditional household saving rates in Latin America and the Caribbean may be dragged down by the relatively high share of consumption in health and education services by households in the region compared to households in both control groups. The same cannot be said in the case of durable goods; the share of these expenditures in total consumption (and therefore the alternative saving rates) is smaller in Latin America and the Caribbean than among the comparators.

\footnotetext{
a The household sector in national accounts typically includes households, unincorporated businesses and non-profit institutions serving households (NPISH). Household income is drawn from national labor statistics, in turn based on business and government payroll data; the overall income of unincorporated business may be inputted from extrapolating the average income of self-employed workers. Government accounts provide information on social contributions, benefits, transfers and tax payments that are required to compute disposable income. Household consumption is computed from retail sales figures compiled by national institutes of statistics, after deducting the portion of sales going to firms as intermediate consumption or investment.

b See Ravallion et al. (2003) for a measure in consumption estimates across data sources. For evidence specific to Latin America and the Caribbean, see Bebczuk et al. (2015), HernaniLimarino, Jiménez, and Mena (2015), and Székely, Mendoza and Karver(2015).

c For example, Hurst, Li, and Pugsley (2014) find that the self-employed in the United States underreport their income by 30 percent and that this has important implications for the measurement of savings.

d Data for Latin America and the Caribbean is from Bebczuk et al. (2015), Székely, Mendoza and Karver (2015), and Hernani-Limarino Jiménez and Mena (2015). Latin American and Caribbean countries include Argentina, Bolivia, Brazil, Colombia, Ecuador, El Salvador, Guatemala, Mexico, Nicaragua, Panama, and Peru. The sample of advanced economies includes France, Japan, and the United States whereas the sample of Asian economies includes Sri Lanka, Taiwan, and Thailand.
}

share of the population with negative saving rates shrinks. This demographic dividend should, therefore, boost aggregate saving rates. This begs the question, how far along the demographic transition is Latin America and the Caribbean? And to what extent are the low relative saving rates driven by the demographic transition? 
Figure 2.7 Dependency Rates (Young and Old), by Region

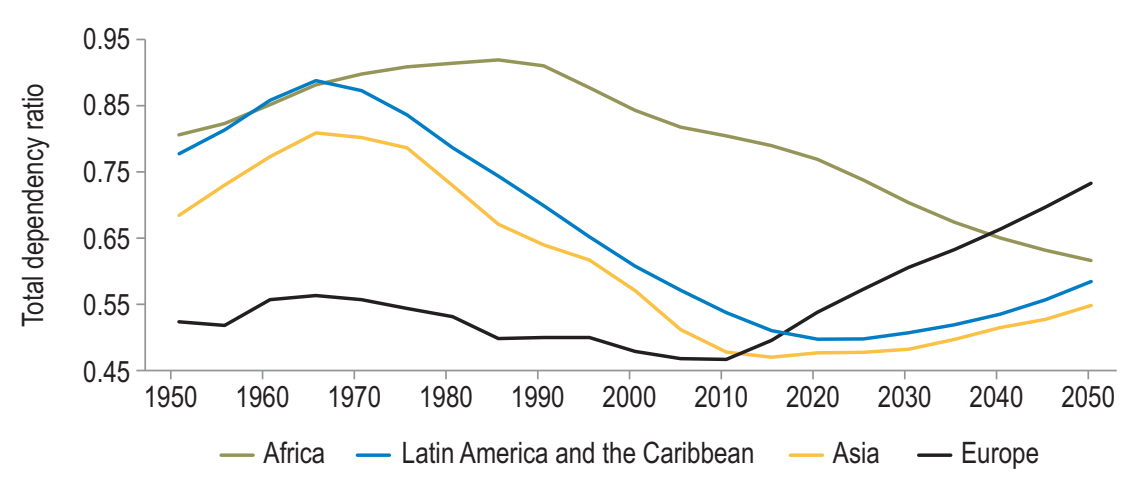

Source: Authors' calculations based on Cavallo, Sánchez, and Valenzuela (2016) and United Nations (2013).

Note: This figure shows the total dependency ratio (the ratio of the population aged 0-14 and older than 65 to the population aged 15-64) across four regions: Europe, Asia, Latin America and the Caribbean, and Africa. A ratio equal to 1 means there is a dependent person for every working age person. The greater the ratio, the more dependent people relative to the working age population.

Dependency rates have declined in all regions, except for Europe, since the 1960s (see Figure 2.7). In Asia, the decline has been rapid: between 1965 and 2010, the number of dependents for every 100 working-age adults fell from 81 to just 48. Interestingly, Latin America and the Caribbean followed a similar path. At the beginning of the demographic transition, the dependency rate was higher than in Asia, with approximately 89 dependents for every 100 working-age adults in 1965. In 2010, that number had dropped to 54. According to United Nations' projections, dependency rates in Asia and Latin America and the Caribbean will bottom out sometime between 2015 and 2020, signaling an end to the demographic dividend for both regions.

The synchronicity of the demographic transition in Asia and Latin America contrasts sharply with the divergence in their saving patterns. Based on this observation, Cavallo, Sánchez, and Valenzuela (2016) study the contribution of demographic factors to saving rates. Interestingly, demographic factors have had a significant impact on saving rates in Asia, but only a small impact in Latin America and the Caribbean. ${ }^{11}$ That is, despite similar, favorable demographic transitions in both regions, and even after accounting for other saving determinants, saving rates did not increase as much in Latin America as they did in Asia.

Whatever factors prevented saving rates from rising in Latin America and the Caribbean despite the favorable demographics-a topic 
discussed in greater detail in Chapter 6-these empirical results confirm that the window of opportunity provided by the demographic dividend is closing fast. Moreover, countries like Guyana, Paraguay, Bolivia, Haiti, Belize, Honduras, Nicaragua, or Guatemala, among a few others where dependency rates have still not reached bottom (see Chapter 6 for a detailed list of where each country in the region lies along the demographic transition), should not count on shifting demographics per se to automatically boost saving rates. Instead, during this stage, they should actively promote private savings-both mandatory (see Chapter 7) and voluntary (see Chapter 9).

\section{Too Old to Save?}

People change their saving patterns over the course of their lifetime to meet their varying wants and needs. The expected saving pattern is for young households to borrow, working-age adult households to save, and older households to dissave once they reach retirement. In Latin America and the Caribbean, household saving rates increase with the age of the household head- but they do not drop after retirement! Saving rates increase for the vast majority of households' life cycle, reaching their peak at age bracket 55-59 to then stabilize around 15 percent after age 60 (see Figure 2.8). In contrast, in the United States, saving rates rise only until age 40-44 and then drop steadily thereafter.

Recent research confirms that saving rates remain relatively high even for households already at retirement age (Székely, Mendoza, and Karver, 2015; Tovar and Urrutia, 2014; Hernani-Limarino, Jiménez, and Mena, 2015). Unfortunately, people saving throughout their old age is not necessarily a good sign. Instead, it may reflect the distortions that high levels of labor informality, job insecurity, and low formal pension coverage generate on saving capacity during working-age years in Latin America. Working-age adults in the region simply do not save enough for retirement. This explains why older Latin Americans continue to work and save (more about this in Chapters 7 and 9).

Evidence from the Inter-American Development Bank's Base of the Pyramid (BoP) Survey (Box 2.3) shows that the savings behavior of households headed by people aged 55 to 65 is similar to that of households headed by younger people. Moreover, the proportion of older heads of household who work is 38 percent in Brazil, 48 percent 
Figure 2.8 Household Saving Rates by Age Group in Latin America and the Caribbean

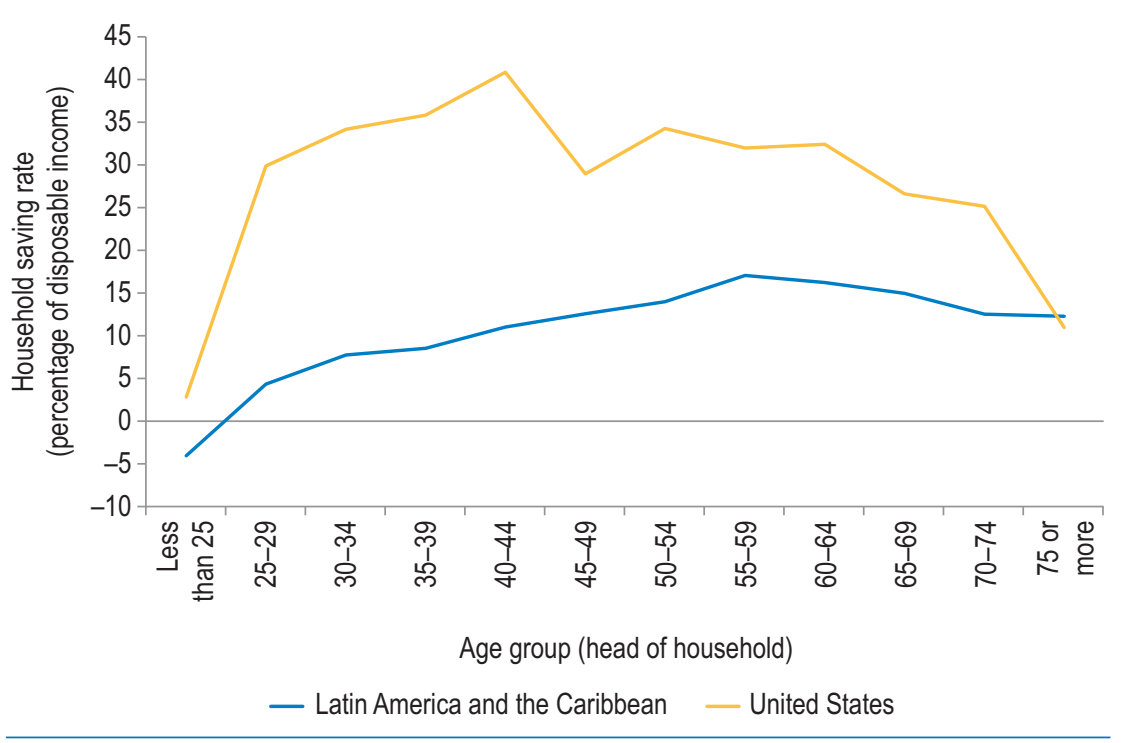

Source: Authors' calculations based on Gandelman (2015a).

Note: All estimates are based on the most recent data available in each country. The Latin American and Caribbean region is comprised of the simple average of: Argentina, Bahamas, Barbados, Bolivia, Brazil, Chile, Colombia, Costa Rica, Ecuador, Honduras, Mexico, Nicaragua, Panama, Paraguay, Peru, Trinidad and Tobago, and Uruguay.

in Mexico, and 81 percent in Peru. Older household heads earn nearly half of their households' monthly labor income and are more likely to be employed in the informal sector compared to younger household heads. Despite their active participation in the labor force, less than one-third of these households enjoys a pension plan through the head of household (21 percent in Peru, 23 percent in Mexico, and 36 percent in Brazil).

Both labor market distortions and limited retirement savings during working-age years force the elderly across Latin America and the Caribbean to keep working and saving beyond their retirement age. Moreover, this phenomenon is becoming more acute; with increases in life expectancy, people are living longer-and most of those extra years are in retirement. (Bloom, Canning, and Sevilla, 2001).

\section{Higher Income, Greater Saving}

People who earn more, save more (See Figure 2.9). ${ }^{12}$ Rich households in the region save significantly more than poor households (as a share of 
Figure 2.9 Household Saving Rates by Income Deciles

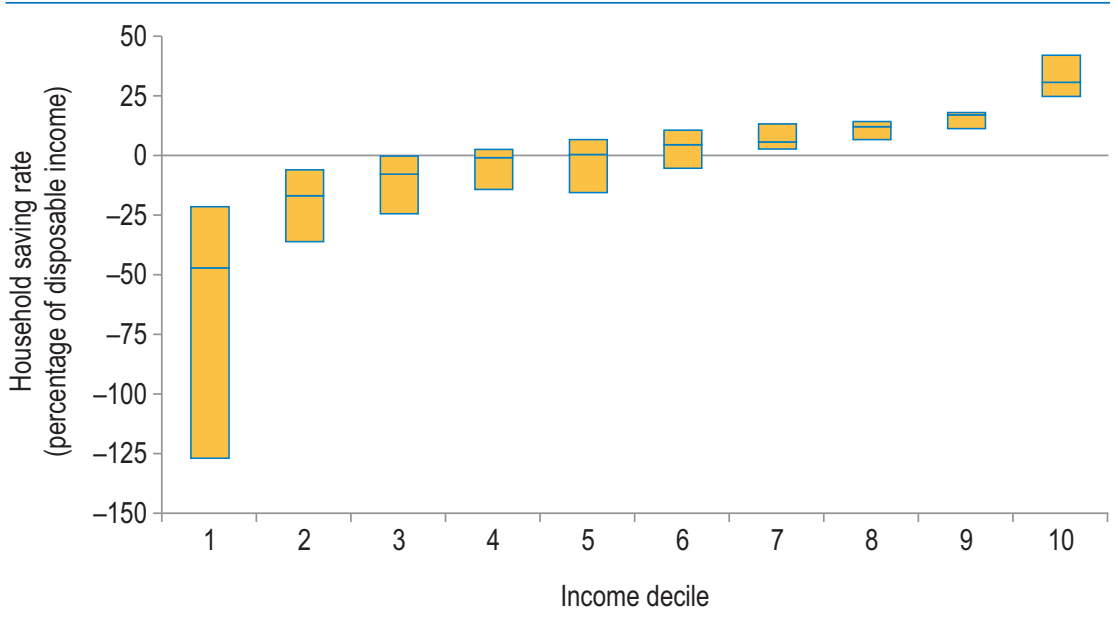

Source: Authors' calculations based on Gandelman (2015a).

Note: All estimates are based on the most recent data available in each country. The Latin American and Caribbean region is comprised of the simple average of: Argentina, Bahamas, Barbados, Bolivia, Brazil, Chile, Colombia, Costa Rica, Ecuador, Honduras, Mexico, Nicaragua, Panama, Paraguay, Peru, Trinidad and Tobago, and Uruguay.

their incomes) in 10 out of 14 countries with available data (Gandelman, 2015b). ${ }^{13}$

In most countries of the region, more than one-third (and sometimes half) of all households spend more than they earn, which means they display negative saving rates. These households tend to be relatively poor. However, negative saving rates do not seem to be financed by access to credit (Bebczuk et al., 2015), which suggests that these negative rates are attributable to income and consumption misreporting (see Box 2.2). ${ }^{14}$

But measurement-error notwithstanding, since highest income earners have higher saving rates than the relatively poor, it follows that saving by the wealthiest households accounts for the vast majority of aggregate household saving in the region. ${ }^{15}$ Indeed, the median country in each country-specific income decile has a positive saving rate only in the top five deciles (see Figure 2.9). When considering all households with positive net saving rates, irrespective of their income level, an average of 53 percent of these total saving flows are generated by the top income decile alone (Bebczuk et al., 2015).

The bottom line is that household saving is unequally spread along the income distribution. Most of the household saving is done by the 
highest income earners. The lack of savings is thus a particularly acute problem for the poor.

\section{Lower-Income Savers: Little to Show for their Efforts}

Negative saving rates among lower-income households suggest that the relatively poor are net borrowers. Observing their saving habits through more specialized instruments (Box 2.3) tells a more complete

\section{BOX 2.3. MEASURING HOUSEHOLD SAVING DIRECTLY}

Specialized and in-depth instruments such as financial surveys help provide a more accurate characterization of households' saving behavior. The use of these instruments allows household saving stocks and regular saving deposits to be measured directly and at higher frequencies than household surveys. ${ }^{\text {a }}$ In particular, the comparison of the money set aside for saving purposes and accumulated saving stocks can be informative about the dynamics of saving at the household level, providing a better understanding of the observed saving rates. For instance, estimates of saving computed as residuals of income and consumption over the course of a year may hide a high turnover of savings at a higher time frequency.

However, the measures of saving derived from financial surveys are not comparable with the indirect measures computed as residuals from either national accounts or household surveys. Instead, financial surveys usually capture saving flows by directly asking households how much they set aside for saving purposes during a given period. Households that do not save will not report any flow into saving instruments; therefore, the corresponding saving estimates are bounded from below at zero. Instead, household surveys and national accounts measure net saving flows over a given time period, which implies that estimated saving can be negative if consumption is financed by depleting saving stocks and/or credit during the relevant period.

Between late 2014 and early 2015, the Research Department and Opportunities for the Majority divisions of the Inter-American Development Bank carried out extensive household surveys in the urban areas of Brazil, Mexico, and Peru. ${ }^{b}$ These surveys were a hybrid between a traditional household survey and a financial survey. Targeted respondents were household heads (75 percent) or their spouses ( 25 percent) between the ages of 18 and 65 . The main objective of these surveys was to identify consumption patterns and unmet demands of poor and middle-income households in several areas, including health, education, technology, housing, and financial services. The target population was the Base of the Pyramid, which consists of individuals 
BOX 2.3. (continued)

living on US\$10 or less per day per capita, at purchasing power parity (PPP) exchange rates..$^{c}$ Due to the nature of the sample restrictions, income data were collected. In addition, the survey collected information on socioeconomic, demographic, and behavioral profiles, with a special emphasis on financial practices, attitudes, and behavior, such as intertemporal and risk aversion preferences, saving patterns, and indebtedness behavior.

a Financial diaries are an extremely useful tool to measure cash flows and financial operations at the household level. However, the level of transaction detail, the frequency of the visits, and the logistics for reaching the poorest are constraints that impose very small sample sizes.

b The samples in all three countries are nationally representative at the urban level. The survey had a probabilistic, two (or three)-stage stratified sampling design where stratification was at the regional level in all three countries.

c See Ferreira et al. (2013) for more details on the definition of this per capita income cutoff.

and complex story: the poor constantly make saving deposits, although mostly into informal instruments. Even more importantly, these inflows into saving instruments represent a relatively important share of their monthly incomes.

The average household in the Base of the Pyramid Survey sample in Peru and Mexico sets aside 6 and 7 percent of its monthly income, respectively. In Brazil, the monthly deposit rate into saving vehicles is substantially lower at 1 percent of monthly income. Restricting the sample to households with positive deposits into saving instruments, monthly saving deposits are, on average, 12 percent of household income in Peru, 23 percent in Mexico, and 8 percent in Brazil. Despite these flows, the accumulated saving stocks (that is, the sum of net saving flows) are not very large, which means that these households regularly deplete their saving stocks. Average saving stocks are 83, 71, and 94 percent of monthly income in Mexico, Peru, and Brazil, respectively. In other words, the average household that saves in Mexico, for example, holds a stock of savings that is equivalent to approximately 3.6 months' worth of saving deposits.

For what do households use their savings? Figure 2.10 plots the percentage of households in each country that declare saving with a given purpose in mind, where multiple uses may coexist. In Mexico and Peru, over half the households save to acquire assets or make investments, while only one-quarter of households in Brazil save with this objective in mind. A large share of households also saves to cover daily expenses or 
Figure 2.10 Use of Savings among Households at the Base of the Pyramid

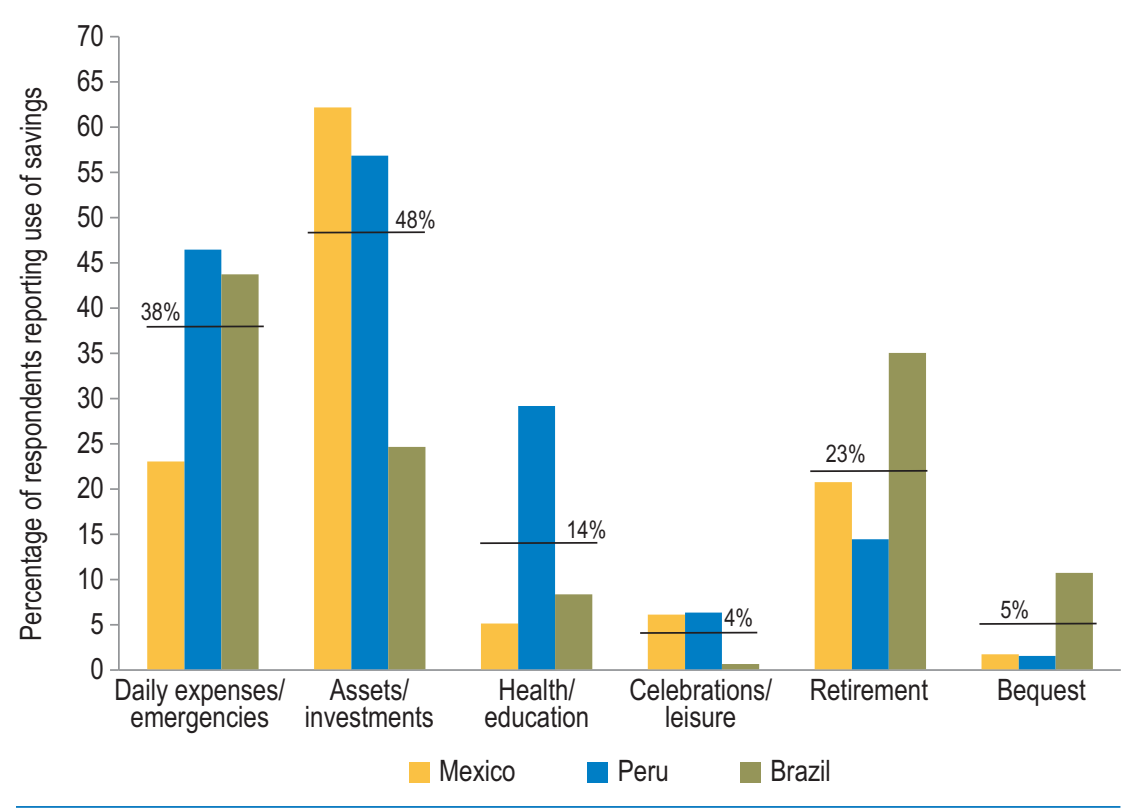

Source: Financial survey estimates are authors' calculations based on the Base of Pyramid (BoP) Survey.

Note: Percentages add up to more than 100 percent because multiple responses were allowed. Horizontal lines represent the average percentage for each use of savings across the three countries.

emergencies, which is consistent with a high turnover of savings in and out of saving vehicles. Relatively fewer responses included longer-term goals such as investments in health, education, or retirement.

In sum, poorer households move in and out of saving vehicles but do not accumulate large stocks of net savings over time. This pattern makes sense since these households use savings mainly to pay for short-term expenses or to finance investments that require small lump sums, rather than for long-term goals such as financing retirement. This behavior may reflect several factors including poorer households' limited choice of saving instruments and the limited reliability of those saving vehicles (see Chapter 11). Also, some households may find it hard to avoid temptations or resist social pressures within the household or from relatives and friends outside the household (see Chapter 9). Given the importance of savings for individual welfare, it is necessary to understand the reason (or combination of reasons) behind this pattern to improve the design of financial instruments to service the saving needs of poor households. 


\section{The Bottom Line}

National saving rates are low in Latin America and the Caribbean compared to other regions. They are particularly low in the case of private saving which is paradoxically, the largest generator of savings in the economy. The relatively higher absorption of foreign saving has not filled the void; thus total saving (and therefore investment) in the region is comparatively lower.

Over the past few decades, low national saving rates in Latin America and the Caribbean have not reflected adverse demographic factors. In fact, the region has enjoyed a favorable demographic transition since the 1960s, yet saving rates have not increased as expected; the region did not generate savings (buffer stocks) when the dependency rates were falling. Now that the demographic dividend is ending and the population is aging, generating more savings will be both more difficult and more urgent.

This chapter reveals some saving distortions in the region. One of these is that people are forced to continue working and saving even beyond retirement age to compensate for a saving deficit during their more productive working age years. Latin Americans are living longer now, but old age brings them no rest as they must work and save to finance a longer life span.

The lack of adequate saving vehicles to channel household savings creates another slew of distortions. The majority of the net saving is generated by high-income households. However, in an ironic twist, relatively poorer households set aside a significant portion of their income each month for saving purposes. These savings are used mostly to meet their needs for fast cash or assets for their homes or businesses. Rarely do these savings make it into the financial system where they could be channeled to finance the longer-term investments that support individual well-being and national development. 


\section{Notes}

1 See Grigoli, Herman, and Schmidt-Hebbel (2014) for the most recent and comprehensive review on the implications of different consumption theories on saving behavior.

2 For example, Coeurdacier, Guibaud, and Jin (2015) present a model in which demographic factors, the age profile, and heterogeneous income growth across generations interact with credit constraints, resulting in asymmetric saving patterns across countries.

3 This book uses country groupings defined as follows, unless otherwise noted. Advanced Economies: Australia, Austria, Belgium, Canada, Cyprus, Czech Republic, Denmark, Estonia, Finland, France, Germany, Greece, Ireland, Israel, Italy, Japan, Latvia, Lithuania, Luxembourg, Malta, Netherlands, New Zealand, Norway, Portugal, San Marino, Slovak Republic, Slovenia, Spain, Sweden, Switzerland, United Kingdom and United States. Emerging Asia: China, Hong Kong, Indonesia, Malaysia, Republic of Korea, Singapore, Taiwan and Thailand. Latin America and the Caribbean: Argentina, Bahamas, Barbados, Belize, Bolivia, Brazil, Chile, Colombia, Costa Rica, Dominican Republic, Ecuador, El Salvador, Guatemala, Guyana, Haiti, Honduras, Jamaica, Mexico, Nicaragua, Panama, Paraguay, Peru, Suriname, Trinidad and Tobago, Uruguay and Venezuela. Sub-Saharan Africa: Angola, Benin, Botswana, Burkina Faso, Burundi, Cabo Verde, Cameroon, Central African Republic, Chad, Comoros, Democratic Republic of Congo, Republic of Congo, Côte d'Ivoire, Equatorial Guinea, Eritrea, Ethiopia, Gabon, The Gambia, Ghana, Guinea, Guinea-Bissau, Kenya, Lesotho, Liberia, Madagascar, Malawi, Mali, Mauritius, Mozambique, Namibia, Niger, Nigeria, Rwanda, Sao Tome and Principe, Senegal, Sierra Leone, South Africa, South Sudan, Swaziland, Tanzania, Togo, Uganda, Zambia and Zimbabwe.

4 Estimated based on Becerra, Cavallo, and Noy (2015), who perform reduced form regression analysis in the tradition of Loayza, SchmidtHebbel, and Servén (1999) and Grigoli, Herman, and Schmidt-Hebbel (2014).

5 The edges of the lines in the plot exclude outliers in statistical terms.

6 The country groupings "Advanced Economies" and "Emerging Asia" categorize countries along two dimensions that tend to induce high national saving rates: high income levels and rapid growth rates, respectively (see Grigoli, Herman, and Schmidt-Hebbel, 2014). Therefore, 
using these country groupings is bound to make saving rates in Latin America and the Caribbean look lower. Nevertheless, Latin America and the Caribbean, with its average saving rate of 17.5 percent from 1980 to 2014, exhibits lower national saving rates than other regional country groupings defined in the World Bank classification.

7 LAC-7 is a group consisting of Argentina, Brazil, Chile, Colombia, Mexico, Peru, and Venezuela that jointly comprise over 90 percent of the regional GDP.

8 In the case of Bebczuk and Cavallo (2016), the effective sample is 47 countries-eight of which are in Latin America and the Caribbeanover 1995-2013. In the case of Grigoli, Herman, and Schmidt-Hebbel (2015), the effective sample comprises 48 countries over 1981-2012.

9 The average hides a significant degree of cross-country heterogeneity. For example, Székely, Mendoza, and Karver (2015) show that, in the case of Mexico, household saving accounts for 55 percent of domestic saving from the national accounts.

10 See Bebczuk and Cavallo (2016) for a recent survey of the literature on the theoretical and empirical evidence on why households do not pierce the corporate veil.

11 Cavallo, Sánchez, and Valenzuela (2016) show that dependency rates explain, on average, up to 22 percent of the variance of saving rates in Asia, and only 3 percent of the variance in Latin America and the Caribbean. This result contrasts with Grigoli, Herman, and SchmidtHebbel (2015), who find that demographic dependency is as important in Latin America and the Caribbean as elsewhere. Two differences explain the varying results. First, Grigoli, Herman, and SchmidtHebbel (2015) focus on private saving, while Cavallo, Sánchez, and Valenzuela (2016) focus on private plus public saving. Second, Grigoli, Herman, and Schmidt-Hebbel (2015) focus on "old age dependency," while Cavallo, Sánchez, and Valenzuela (2016) include young dependency and life expectancy as additional demographic variables, and thus their results relate to the three demographic factors.

12 Many studies document that household saving rates rise with income. See Butelmann and Gallego (2000)-for Chile- and Grigoli, Herman, and Schmidt-Hebbel (2014) for the world. Bebczuk et al. (2015) and Gandelman (2015a) document the same fact for Latin America and the Caribbean.

13 Gandelman (2015b) correlates saving rates and household lifetime income, while instrumenting the latter with the education level of the 
head of household and spouse. The study uses a wealth index as a proxy for lifetime income as an additional identification strategy.

14 In particular, they find that households with negative saving rates are headed by people with fewer years of schooling, lower labor formality rates, and a somewhat higher participation of government transfers and remittances in total income. All these factors could be linked to income underreporting. It may also be that excess consumption is financed with past saving stocks, but this is not possible to check with household survey data.

15 For country-specific statistics, see Gandelman (2015a).

(c) $\$$ This chapter is distributed under the terms of the Creative Commons Attribution-NonCommercial-NoDerivatives 3.0 IGO license (http://creative commons.org/licenses/by-nc-nd/3.0/igo/) and may be reproduced with attribution to the Inter-American Development Bank (IDB) and for any non-commercial purpose. No derivative work is allowed.

Any dispute related to the use of the works of the IDB that cannot be settled amicably shall be submitted to arbitration pursuant to the UNCITRAL rules. The use of the IDB's name for any purpose other than for attribution, and the use of IDB's logo shall be subject to a separate written license agreement between the IDB and the user and is not authorized as part of this CC-IGO license. Note that the link provided above includes additional terms and conditions of the license.

The images or other third party material in this chapter are included in the work's Creative Commons license, unless indicated otherwise in the credit line; if such material is not included in the work's Creative Commons license and the respective action is not permitted by statutory regulation, users will need to obtain permission from the license holder to duplicate, adapt or reproduce the material. 